\title{
The Rich Demystified \\ A Reply to Bach, Corneo, and Steiner (2008)
}

\author{
MARTIN JACOB \\ RAINER NIEMANN \\ MARTIN WEISS
}

CESIFO WORKING PAPER NO. 2478

CATEGORY 1: Public FinANCE

NOVEMBER 2008

An electronic version of the paper may be downloaded

- from the SSRN website:

www.SSRN.com

- from the RePEc website:

www.RePEc.org 


\title{
The Rich Demystified A Reply to Bach, Corneo, and Steiner (2008)
}

\begin{abstract}
The contribution Bach, Corneo, and Steiner (2008) has argued that "the rich" do not pay taxes adequately in relation to their income, finding, for instance, an effective tax rate of only $38.1 \%$ for the $0.001 \%$ fractile of German income taxpayers in 2001 . This result contrasts sharply with the legislated top marginal income tax rate of $48.5 \%$. We subject the results contained in Bach, Corneo, and Steiner (2008) to a rigorous analysis: We find major flaws and inconsistencies with regard to methodology, i.e. the omission of corporate taxes and intertemporal aspects of taxation. Restating basic rules for the measurement of effective tax rates, we provide values for what we term the "comprehensive nominal tax rate" (CNTR) and show that the headline result in Bach, Corneo, and Steiner (2008) of 38.1\% is underestimated by over 12 percentage points. As an important distributional result, the CNTR increases with increasing taxable income.
\end{abstract}

JEL Code: D31, H00, H24, H25.

Keywords: top incomes, income taxation, taxing the rich, comprehensive nominal tax rate.

Martin Jacob
Department of Economics
University of Tübingen
Mohlstr. 36
72074 Tübingen
Germany
martin.jacob@uni-tuebingen.de

Martin Jacob

Department of Economics

Mohlstr. 36

Germany

martin.jacob@uni-tuebingen.de

\author{
Rainer Niemann \\ Karl-Franzens-University Graz \\ Universitätsstraße 15/FE \\ 8010 Graz \\ Austria \\ niemann@uni-graz.at
}

\author{
Martin Weiss \\ Department of Economics \\ University of Tübingen \\ Mohlstr. 36 \\ 72074 Tübingen \\ Germany \\ martin.weiss@uni-tuebingen.de
}




\section{Introduction}

Discussions concerning the taxation of "the rich" have dominated the German political and social landscape for a long time. The perception that "the rich" do not adequately contribute their share to the public finances is deep-rooted, yet scientific tests of this presumption are quite rare. The contribution by Bach, Corneo and Steiner $(2008)^{1}$ constitutes an attempt to add to the public discourse by calculating the tax burden weighing on "the income rich" in the years 1992 to 2002. To this end, BCS employ a dataset merged from the German socio-economic panel (GSOEP), provided by the DIW, Berlin, and the whole population of income tax returns for Germany for the years 1992, 1995, 1998, 2001 and 2002. Their major finding is an "effective average income tax rate of the German economic elite - the top $0.001 \%$ quantile of the gross income distribution - ... (of) about 34 percent, which is well below the legislated tax rate." They also report significant variation over time, with the rate ranging from a low in 1995 of $31 \%$ to a high in 1998 of $45 \%$. Similar results are reported for the top $0.0001 \%$ quantile where the average income tax rate drops to only $32.0 \%$ for 2002 (BCS, p. 17).

While this result seems shocking at first blush and might lead one to conclude that the superrich are not contributing adequately to the German tax base, we discuss possible reasons for it and provide appropriate remedies. BCS restrict their analyses to the income tax burden. Yet, while some economic activities, e.g. workers' labor supply, are subject to personal income taxation alone, this is not true for the case of income from business activity where both the local trade tax and, for incorporated businesses, the corporation tax reduce the sole destination of earnings, the consumption of a natural person. As it happens, the top $0.001 \%$ quantile $^{2}$ of the German taxpayers derive their major earnings stream from business activity ( $68.84 \%$ of adjusted gross income) while fully $94.96 \%$ report any earnings from this source.

BCS conduct their analysis with regard to a single year - necessitated by the lack of panel data sets covering taxation in Germany - and thus neglect the inter-temporal aspect of economic activities that investment theory is imbued with. This point is made all the more poignant as the inter-temporal aspect of taxation "creeps in through the backdoor": German Income Tax Law allows taxpayers to conduct unlimited carry-forwards and limited carry-backs of tax losses, which BCS completely ignore. If carry-forwards and carry-backs lower the tax payments due in the year under examination but are disregarded for purposes of the income tax burden attributed to this year, the resulting number is biased toward an artificially low tax rate.

Furthermore, BCS interpret the deduction of capital expenses and accruals, i.e. the transformation of cash flows into tax bases, as "loopholes". The term "loophole" is also applied to the losses resulting from the income type "renting and leasing" which is subsequently truncated arbitrarily at $-5.000 €$. In the same vein, BCS attempt to explain the astonishingly low tax rates that they find with reference to terms such as "loophole", which appears five times throughout the text, "tax base erosion" (twelve appearances) and "tax avoidance" (nine appearances).

Additionally, BCS devote an entire section to the definition of an "adjusted gross income" which differs markedly from the legal definition supplied by the income tax code.

1 Henceforth BCS. As there are three almost identical versions of the paper, we cite the most recent and important discussion paper series where it has been published.

2 Measured by adjusted gross income (defined in section 3.2). Note that jointly filing couples would count as one unit in this analysis. 
It also diverges from the well-established and readily available concept of economic profits as a measure of economic income. Being derived from investment theory, the notion of economic profits is based on a multi-period concept. Similarly, the concept of "effective tax rates" is only rendered meaningful in an inter-temporal perspective.

We thus recap the theory behind the academic concepts applied in BCS. Along the way, we highlight the instances where these multi-period concepts are not amenable to cross-sectional, i.e. single period, analyses. A frictionless transfer is not feasible, leading us to conclude that any tax rate computed on the back of the available data can only be interpreted as a nominal tax burden. As a prominent example, the apparent rule that faster depreciation today translates into less depreciation in the next year, serves to highlight the problematic nature of a single-period view: Eventually, today's lower tax base catches up with the taxpayer. We tentatively improve on the numbers provided by BCS, remedying several of the points of critique above and labeling the results as a "comprehensive nominal tax rate". Ironically, and in contrast to BCS, many publications concerning business taxation neglect the personal tax and solely integrate the corporate tax. We reestablish the link between corporate and personal taxation that is quite standard in modern economic thought. Our argumentation dissects their definition of an "effective tax rate", where we argue that ultimately, the numerator, the denominator and the number itself are misleading.

We provide an extensive analysis of "comprehensive nominal tax rates" on the population of German taxpayers in 2001. The spotlight put on top incomes by BCS is mirrored in our analysis. Our tentative measure of a tax rate that explicitly accounts for a comprehensive tax burden, encompassing a reasonable definition of pre-tax economic income and an enlarged set of taxes weighing on it, results in "comprehensive nominal tax rates" that are up to 12 percentage points higher than the tax rates calculated by BCS. As it turns out, the finding of a higher tax rate is robust across the entire income distribution and increases in income.

The rest of the paper is organized as follows: In section $\mathbf{2}$, we critically examine the theoretical approach adopted in BCS. In section 3, we provide an extensive analysis of "comprehensive nominal tax rates" on top incomes and show that a comprehensive, bird's eye view of the tax burden for the income rich leads to sharply different conclusions. Section 4 concludes. An Appendix provides additional statistical material.

\section{Theoretical Examination of the Approach in BCS}

\subsection{The BCS Approach}

The BCS contribution is part of a broader literature that researches the issues of inequality and its reduction through government policies, in particular through taxation, and the degree of "effective progressivity" that the German tax system exhibits. BCS cite most of these contributions in their chapter 1 . The authors themselves have contributed to the subject matter before, in Bach et al. (2005), with a focus on tax issues, and Bach et al. (2007), with a focus on the distribution of market incomes. These papers share several common traits that we subject to a critical examination below, in particular the same database $^{3}$ and the focus on the income tax burden alone ${ }^{4}$. The correction for presumed

$\begin{array}{ll}3 & \text { Cf. subsection } 3.1 \text {. } \\ 4 & \text { Cf. subsection 2.5. }\end{array}$ 
"tax avoidance strategies" or the - arbitrary - truncation of losses from renting and leasing ${ }^{5}$ provide other examples.

Bach et al. (2005, sec. 4.3) also employ the concept of effective tax rates that we discuss in subsection 2.2. Table 11 in that chapter is quite similar in structure to table 4 of BCS: Both tables consistently find effective tax rates for the top $1 \%$ fractile of the German income tax population well below the legislated nominal tax rates, leading to the conclusion "Tax progression is real and strong, although definitely not as strong as the statutory tax rates would imply." (Bach et al., 2005, p. 24).

\subsection{Effective Tax Rates}

The development of effective tax rates in the literature was instigated by King and Fullerton (1984) and extended by Devereux and Griffith (1999). This strand of the literature has witnessed huge growth since then (Knirsch, 2007). It is based on the notion that nominal tax rates as stipulated by tax codes do not adequately express the tax burden weighing on economic activities. Quite to the contrary, nominal tax rates are meaningless numbers because they are applied to a tax base that does not coincide with investors' economic goals. Investment theory is based on the notion of investors' goals defined as the discounted consumption possibilities created by an investment over and above those readily available from some standard investment, i.e. a savings account. If the definition of the tax base in the tax code does not hit these goals but anything other than them, then the nominal tax rate is no longer a valid expression of the reduction of the degree to which investor reach their goals after tax. A comparison of nominal tax rates, e.g. across countries, is consequently not meaningful.

A very general formulation of effective tax rates (ETR) that remedies the aforementioned deficiencies is thus (Niemann et al., 2003)

$$
\begin{aligned}
\text { ETR }= & \frac{\text { Economic goal before tax }- \text { economic goal after tax }}{\text { Economic goal before tax }}= \\
& \frac{\text { Tax wedge }}{\text { Economic goal before tax }} .
\end{aligned}
$$

Importantly, the concept of effective tax rates is inherently designed to address a multiperiod context because it builds on investment theory. Departing from equation (1), the "economic goal" has been defined in various ways in the literature, e.g. as net present values, final values or rates of return as defined by Baldwin (1959). Regardless of the specific figure employed to calculate equation (1), they all address multi-period contexts. If this property of effective tax rates is disregarded, the connection to the literature is severed.

In contrast to the multi-period effective tax rate models, BCS, p. 10 derive their measure of effective taxation from a single period calculus. Single-period expressions, as they are typical of cost accounting or producer rents in microeconomic theory, are unlikely to cover the tax burden on multi-period investments such as real estate or shareholdings adequately. What would a single-period ETR be able to deliver in terms of information about tax effects, i.e. tax base, tax rate and time effects? As time effects are by the nature of the construction of a single-period ETR out of the equation, only tax base and tax rate effects can be detected.

\footnotetext{
5 Cf. subsection 2.5.3.
} 
BCS not only deliver one effective tax rate, but rather a whole vector of effective tax rates over points in time. They define ${ }^{6}$ their "effective average tax rate", denoted here as $E T R_{t}^{B C S}$, as the assessed income tax liability (plus solidarity surcharge) paid in time $t$, denoted as $P I T_{t}$, divided by the adjusted gross income in $t$, denoted as $A G I_{t}$.

Consider $A G I_{t}$ being the economic goal before tax and $A G I_{t}-P I T_{t}$ being the economic goal after tax, then $E T R_{t}^{B C S}$ can be written as the well-known effective tax rate approach from equation (1).

$$
E T R_{t}^{B C S}=\frac{A G I_{t}-\left(A G I_{t}-P I T_{t}\right)}{A G I_{t}}=\frac{P I T_{t}}{A G I_{t}} .
$$

The interpretation of $E T R_{t}^{B C S}$ cannot be the same as in a multi-period approach as one year's income is not an economic goal in itself. Therefore, $E T R_{t}^{B C S}$ delivers a tax rate that tells us how much in taxes one investor paid in relation to an - imprecise - measure of income in one year, i.e. an adjusted nominal tax rate.

Furthermore, BCS establish entire time series of $\mathrm{ETRs}^{7}$, which might leave the impression of an inter-temporal perspective being adopted. Crucially, though, the available micro datasets for Germany do not allow one to track taxpayers' behaviour over time. Several cross-sectional datasets appended to each other cannot make up for this deficiency. They do not contain unique id variables which could establish a link between them. There is no mention of this problem in BCS, nor is an idea of how to interpret the varying tax rates given.

\subsection{Different Notions of Income}

Quite apart from the doubts related to the interpretation of $E T R_{t}^{B C S}$ as an ETR, the definition of the income employed to compute this number leads to yet another problem. Consider for example an individual who purchases $0.5 \%$ of the equity of an incorporated business $^{8}$ for $100 €$. After holding the non-dividend paying stocks for 5 years, it is sold for a nominal capital gain. Discounting the proceeds of the share sale amounting to $133.82 €$ at the prevailing interest rate $i=6 \%$, the investment turns out to be marginal before tax.

Applying the concept of economic profits, the microeconomic view would consider the individual to have income each year due to an appreciation in each period: with each passing year, the final payment in $t=5$ draws nearer. In a macroeconomic view, the national accounts would include this gain in $t=5$. The notion of income espoused in the German tax code, the taxable income (fiscal view), would lead to zero income since the German income tax code of 2001 did not tax capital gains from minority shareholdings that had been realized after the expiration of the speculation period of one year.

The three definitions result in periodical income (economic profit), income at realization (national accounts), or in no income at all, as shown in table $\mathbf{1}$ on the next page. Adding to the confusion thus created, BCS applied a fourth definition of income, their adjusted gross income (AGI), that they derived from taxable income ${ }^{9}$. In microeconomic approaches, however, the concept of the economic profit is well established and remains the yardstick for economic income for which the AGI does not even serve as a rough approximation.

6 BCS, p. 15.

7 Cf. table 4 on page 17.

8 Mainly AGs and GmbHs according to German company law.

9 A detailed discussion of the derivation can be found in subsection 3.2 on page 15 . 
Table 1. Differing Income Definitions

\begin{tabular}{rrccc}
\hline & & \multicolumn{3}{c}{ Income according to } \\
\cline { 3 - 5 }$t$ & Cashflow & Economic Profit & National Accounts & German Tax Law until 2008 \\
\hline 0 & -100.00 & 0.00 & 0.00 & 0.00 \\
1 & 0.00 & 6.00 & 0.00 & 0.00 \\
2 & 0.00 & 6.36 & 0.00 & 0.00 \\
3 & 0.00 & 6.74 & 0.00 & 0.00 \\
4 & 0.00 & 7.15 & 0.00 & 0.00 \\
5 & 133.82 & 7.57 & 33.82 & 0.00 \\
\hline
\end{tabular}

We now provide a simple numerical example of the time-series behaviour of the singleperiod ETRs based on the AGI by BCS and on the economic profit. Given the prominence accorded to income from renting and leasing, we model a taxpayer over a period of five years and highlight the result of a narrow focus on data for one specific year.

Suppose an individual taxpayer invested 1 million $€$ in real estate, where the Income Tax Code stipulates a straight-line depreciation rate of $2 \%$ per year. From the income tax statistic, we observe the income from renting and leasing. Multiplying this income with the investor's marginal tax rate gives the personal income tax in $t, P I T_{t}$, which is attributable to the real estate investment. Adding the depreciation allowances at each point in time, we can derive the cash flow $C F_{t}$. At the end of $t=5$ the house is sold for $800,000 €$, the taxpayer realizes a capital loss of $100,000 €^{10}$. The investment's economic profit, $E P_{t}$ is defined as cash flow in $t$ less economic depreciation. BCS' adjusted gross income equals the tax base except for losses from renting and leasing exceeding $5,000 €$, which are truncated.

Table 2. Derivation of the Cash Flow

\begin{tabular}{llrrrrr} 
& $t$ & 1 & 2 & 3 & 4 & 5 \\
\hline$(1)$ & CF $_{t}$ & 200.00 & 0.00 & 250.00 & 4.56 & 800.00 \\
$(2)$ & Depr $_{t}$ & 20.00 & 20.00 & 20,00 & 20.00 & 20.00 \\
$(3)$ & TaxBase $_{t}$ & 180.00 & -20.00 & 230.00 & -15.44 & -120.00 \\
$(4)$ & PIT $_{t}$ & 75.60 & -8.40 & 96.60 & -7.78 & -50.40 \\
\hline$(5)$ & EP $_{t}$ & 60.00 & 51.60 & 54.69 & 42.98 & 45.28 \\
$(6)$ & AGI $_{t}^{\text {BCS }}$ & 180.00 & -5.00 & 230.00 & -5.00 & -105.00 \\
\hline
\end{tabular}

Given the economic profit and the adjusted gross income in each period, we compute the vectors of ETRs from equation (2):

Table 3. Comparison of Single Period ETRs

\begin{tabular}{llrrrrr} 
& $t$ & 1 & 2 & 3 & 4 & 5 \\
\hline$(4) /(5)$ & $E T R_{t}^{E P}$ & $126.00 \%$ & $-16.28 \%$ & $176.61 \%$ & $-15.09 \%$ & $-111.30 \%$ \\
$(4) /(6)$ & $E T R_{t}^{B C S}$ & $42.00 \%$ & $168.00 \%$ & $42.00 \%$ & $155.60 \%$ & $48.00 \%$ \\
\hline
\end{tabular}

$\overline{10}$ We assume that he can fully offset the loss against other income. 
The variation from $-111 \%$ to $176 \%$ of the "ETR" based on the economic profit and equation (2) indicates the inaccuracy of $E T R_{t}^{E P}$ as a tax burden measure. Applying the BCS definition of the adjusted gross income to this example results in an "ETR" ranging from $42 \%$ to $168 \%$. Hence, even if one applies the universally accepted measure of the economic profit, single period ETRs lack any explanatory power. Any deviation from this concept, such as the adjusted gross income in BCS, does not render the measure meaningful, either.

By contrast, the ETR based on Baldwin rates of return ${ }^{11}$ delivers an ETR of $44.48 \%$, indicating that the real estate investment carries a higher tax burden than the alternative investment since the present value of the economic depreciation is higher than the present value of the deduction allowed by $\S 7$ (4) of the German Income Tax Code. This interpretation would not have been possible with any of the single period "ETRs" as they cannot account for time effects.

\subsection{The Relation between Economic Income and Taxable Income}

The numerical example above has shown that the economic profit and the tax base differ at each point in time and in their time series behaviour. This section discusses the restrictions under which the economic profit can be derived from the taxable income in a single period context and how the resulting single period ETRs can be interpreted. If these restrictions held, then we could use the available cross-sectional data to compute the taxpayer's economic profit and interpret the resulting number.

Consider the earnings $E_{t}^{*}$ as well as the expense $A_{t}^{*}$ to be constant and to be different from the incoming payments $E_{t}$ and the outgoing payments $A_{t}$ respectively, then the cash flow and the tax base evolve as:

$$
\begin{aligned}
& C F_{t}=E_{t}-A_{t} \\
& T B_{t}=E_{t}^{*}-A_{t}^{*} .
\end{aligned}
$$

Under the assumption that the cash flow, the tax base and their components are constant until infinity, the income from the microeconomic view, i.e. the economic profit, is equal to the cash flow but not necessarily equal to the fiscal income. Consequently, the tax base has to be adjusted. The following relation between economic and taxable income has to hold to validate the interpretation of the outcome from cross-sectional data.

$$
E P_{t}=C F_{t}=T B_{t}+\left[E_{t}-E_{t}^{*}\right]-\left[A_{t}-A_{t}^{*}\right]=\text { const } . \quad \forall \quad t
$$

A prominent example for a necessary adjustment is given by the income from dividends under the half income system where both the earnings and the expenses have to be revised. At first, dividends are included with $50 \%$ of the gross distribution in the taxable income. Additionally, the gross dividend is lowered by corporate and local trade tax. Furthermore, consider this shareholding to be debt-financed, then only half of the interests paid can be deducted from the taxable income, while the cash flow was lowered by the full expenses. Consequently, the earnings side as well as the expense side has to be adjusted in order to deliver an accurate measure of the economic profit ${ }^{12}$. Therefore, the taxable dividend has to be adjusted on the earnings side .

The economic profit can only be derived from the taxable income observed in a crosssectional dataset if the following restrictive assumptions hold:

\footnotetext{
11 The pre-tax net present value is zero in order to allow for any meaningful interpretation.

${ }^{12}$ A full overview of adjustments for the individual income fractiles is presented in section 3.2.
} 
- Infinite time horizon,

- Cash flow is constant over time,

- Tax base is constant over time,

- Incorporated businesses do not retain earnings,

- Economic depreciation is equal to deduction allowed by tax code,

- Accumulated tax burden is known for all income fractiles,

- Origin of foreign income, especially dividends, is known

- Capital gains are not realized, since tax burden on capital gains is not measurable.

If these restrictions held, then the application of equation (2) would deliver a tax rate which could be interpreted as the comprehensive nominal tax burden of the economic profit in the examined year.

\subsection{The Tax Burden on Economic Activities}

\subsubsection{Relevant Tax Rules for Incorporated and Unincorporated Business}

With regard to the taxes constituting the tax burden on economic activities, figure 1 highlights those central to the main thrust of our argumentation, emphasizing the importance of the integration of both the personal and the corporate level.

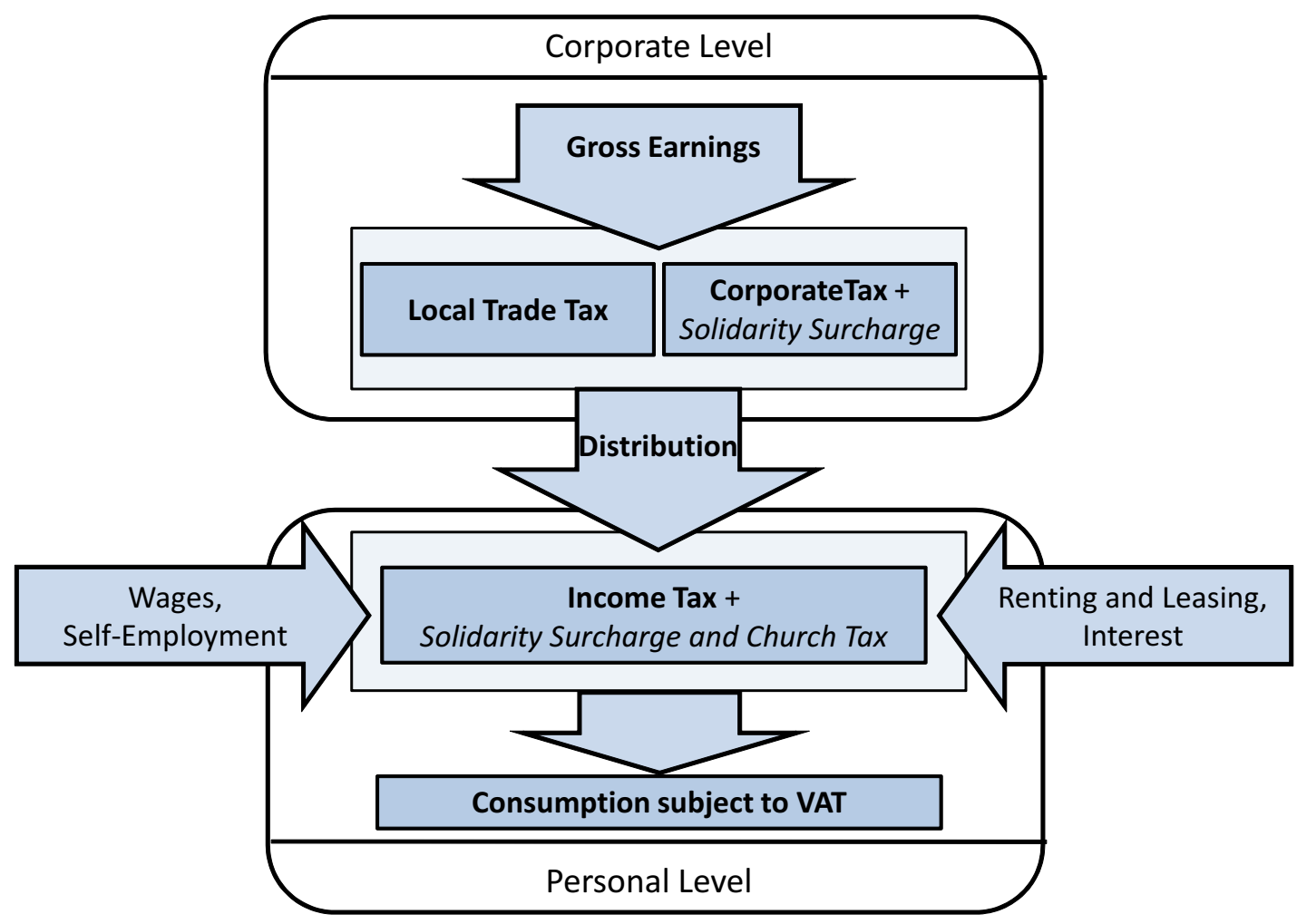

Figure 1. From Gross Economic Activity to Consumption

Each of these taxes comes with its own set of rules concerning the determination of the tax base and tax rates. A priori, it is not possible to discount any of these taxes as irrelevant for the measurement of effective taxation ${ }^{13}$. In particular, the inclusion of

$\overline{13}$ The universe of taxes possibly impacting the tax burden on economic activities exceeds the one in figure 1 and could conceivably include the Value Added Tax and property taxes. 
the tax burden on the corporate level is mandatory and largely uncontroversial: While from a legal standpoint corporate and personal taxes are owed by different legal persons, economists trace profits from their origin on the corporate level to their sole final destination: The consumption of an individual or a household. Along the way, taxation reduces the consumption value repeatedly. For the distributional consequences, it does not matter what a tax is being called and whether it is collected on the corporate or on the individual level.

The refusal of BCS to take into account the enlarged universe of taxes depicted in figure 1 contradicts with the legislator himself: $\S 35$ of the German income tax code establishes a link between the income tax and the local trade tax, providing a relief in the former for the burden represented by the latter ${ }^{14}$. The obvious corollary of this construction, i.e. that the legislator is aware of the accumulated tax burden established by both taxes and the possibility of a substitution between them, is turned on its head in BCS: The relief stipulated in $\S 35$ is incorporated into their calculations, but the concomitant burden of the local trade tax is ignored.

BCS choose to include the Income Tax ${ }^{15}$ and the Solidarity Surcharge on the "Personal Level" in their calculations ${ }^{16}$. There is no explicit explanation of this restriction, nor is this choice self-evident in the light of the foregoing discussion. Interestingly, the corporate level is barely touched upon: The gross dividend before corporation tax is imputed (BCS, p. 9) rather crudely, neglecting the local trade tax burden ${ }^{17}$. The more fundamental decision to omit the corporate level entirely is not made transparent at all and its effect will be the matter of the following paragraphs.

We show the dimension of the underestimation bias in BCS that can be traced back to the neglect of the local trade tax. This bias is prevalent for the rich as the top $1 \%$ quantile $^{18}$ generates $17.89 \%$ of their total income from business activity. The income from unincorporated business is for the top $0.1 \%$ quantile the most important income component with $37.83 \%$ of the gross income. This share rises to $68.84 \%$ for the top $0.001 \%$ quantile and to $78.66 \%$ for the top $0.0001 \%$ quantile respectively ${ }^{19}$.

With regard to this point, we provide a comparison of the comprehensive tax burden and the "narrow tax burden" by BCS for the income from unincorporated businesses in table 4 on the next page. German income tax law allowed taxpayers to deduct the local trade tax from its own tax base and from the income tax base until 2007. Depending on the local municipal rate of the local trade tax, which we fix at $400 \%^{20}$, the initial local trade tax burden, factoring in its deductibility from its own tax base (120), was 20 $(16.67 \%)$. On the remainder (100), income tax - with $48.5 \%$ as the highest marginal rate

\footnotetext{
$\overline{14}$ See table 4 on the facing page.

15 Abbreviated "PIT" in their paper.

16 BCS, p. 15.

17 BCS seem to suggest in their conclusion that a "move from the taxpayer level to the individual level - taking household composition into account - ... seems an interesting topic for future research".

18 The quantiles reported in this section refer to the overall amount of income inferred from the almost $30,000,000$ German tax returns in 2001.

19 Cf. table 10 .

20 This simplification is suspended in our calculations in section $\mathbf{3}$, in favor of a more detailed estimate of the applicable municipal rate: We distinguish between the former east and west. A more detailed analysis on the level of federal states was not allowed by the anonymisation laws.
} 
in 2001 - and solidarity surcharge was due $(51.17)^{21}$. Furthermore, $\S 35$ of the German income tax code provided for additional lump-sum tax relief with regard to the local trade $\operatorname{tax}(9.50)$.

Table 4. Calculation of Tax Liability for an Unincorporated Business

\begin{tabular}{rrcc} 
& & Our approach & BCS \\
\hline$(1)$ & Business Profit=Income & 120 & 100 \\
$(2)$ & Local Trade Tax & -20 & - \\
\hline$(3)$ & Income from Business Activity & $\mathbf{1 0 0}$ & 100 \\
$(4)$ & Personal Income Tax & -51.17 & -51.17 \\
$(5)$ & Paragraph $35^{1}$ & +9.50 & +9.50 \\
\hline$(6)$ & After Tax & $\mathbf{5 8 . 3 3}$ & 58.33 \\
& $C N T R / E T R^{B C S}$ & $51.39 \%$ & $41.67 \%$ \\
\hline
\end{tabular}

${ }^{1}$ Solidarity Surcharge contained in Income Tax Payment as in BCS

From table 4, a tax burden on a business profit of 120 of 61.67 can be inferred, leading to a comprehensive nominal tax rate (CNTR) of $51.39 \%$. BCS' narrow focus on the income tax burden alone - without accounting for the local trade tax paid, but factoring in the tax relief provided for it by $\S 35$ - would calculate a tax burden of 51.17-9.50=41.67 and come up with an "effective tax rate" of $41.67 \%$, almost ten percentage points lower. The "true" tax burden of unincorporated business that represents the most important income source for the rich and superrich is consequently underestimated by BCS. As the observed income tax liability - including the $\S 35$ offset - constitutes the nominator of their ETR, the ETR itself is unambigously biased downward. Worse yet, BCS account for the local trade tax offset in their income tax measure without acknowledging the underlying local trade tax payment that the offset was supposed to mitigate in the first place.

In the same vein, the corporate and the local trade tax is omitted when measuring the tax burden on the income from incorporated business, i.e. income from dividends. The lower numerator - due to the omission - entails a lower effective tax rate. If we take into account the empirically observed concentration of shareholdings in the upper quantiles of the German income distribution, then this effect does not balance out over the entire distribution; instead it biases the results in favor of the impression that the rich do not pay taxes adequately as for the income of incorporated business ${ }^{22}$.

With regard to this point, we compute the resulting bias for distributed profits ${ }^{23}$. We integrate the corporate and the personal level into an exemplary calculation for both the full imputation system (FIS) that was in effect until 2001 and the half income system (HIS) valid from 2001 to $2007^{24}$. To explain the structures, table 5 on the next page

$\overline{21}$ We omit the liability for church tax in all our calculations.

22 The top $1 \%$ quantile received $42.85 \%$ of the dividend and interest income in 2001 . The income from dividends and interests represent the second largest income component for the top $0.1 \%(0.01 \%)$ quantile with $21.22 \%(27.71 \%)$ of gross income. Cf. tables 10 and 11.

23 Consider that a corporation retains earnings. A narrow focus on the personal tax alone would imply these earnings to be temporarily tax-free, while they are evidently reduced by the local trade tax and the corporate tax.

24 The dividends taxable in 2001 were taxed in $95.9 \%$ of the cases under the full imputation system, in $4.1 \%$ of the cases under the half income system. (Source: Income Tax Return (ITR) Data for 2001, own calculations). 
highlights the tax burden for an incorporated business in Germany for both tax systems, where the distribution, which can be directly derived from the ITR dataset, is exogenously set to 100 in row 4 in table 5. The relevant income is given in row 1 with the business profit.

Table 5. Calculation of Tax Liability for an incorporated business under the German full-imputation system and the German half-income system, owners in the highest German tax bracket

\begin{tabular}{rrrrrrrr}
\hline & & \multicolumn{2}{c}{ Our approach } & & \multicolumn{3}{c}{ BCS } \\
\cline { 3 - 4 } \cline { 7 - 8 } & & FIS 2001 & HIS 2002 & & FIS 2001 & HIS 2002a & HIS 2002b \\
\hline$(1)$ & Business Profit & $\mathbf{1 7 5 . 5 7}$ & $\mathbf{1 6 2 . 9 9}$ & & $\mathbf{1 4 6 . 3 1}$ & $\mathbf{1 3 3 . 3 3}$ & $\mathbf{6 6 . 6 7}$ \\
$(2)$ & Local Trade Tax & 29.26 & 27.16 & & - & - & - \\
$(3)$ & Corporation Tax & 61.74 & 35.82 & & - & - & - \\
$(3 a)$ & Distribution Tax Relief & -15.44 & - & - & - & - \\
\hline$(4)$ & Distribution & $\mathbf{1 0 0 . 0 0}$ & $\mathbf{1 0 0 . 0 0}$ & & $\mathbf{1 0 0 . 0 0}$ & $\mathbf{1 0 0 . 0 0}$ & $\mathbf{1 0 0 . 0 0}$ \\
$(5)$ & Tax Base PIT & 146.31 & 50.00 & & 146.31 & 50.00 & 50.00 \\
$(6)$ & Personal Income Tax & 74.86 & 25.58 & & 74.86 & 25.58 & 25.58 \\
$(7)$ & Imputation Credit & 46.31 & - & & 46.31 & - & - \\
\hline$(8)$ & After Tax & $\mathbf{7 1 . 4 4}$ & $\mathbf{7 4 . 4 2}$ & & $\mathbf{7 1 . 4 4}$ & $\mathbf{1 0 7 . 7 5}$ & $\mathbf{4 1 . 0 8}$ \\
$(9)$ & CNTR/ETR $R^{B C S}$ & $59.31 \%$ & $54.34 \%$ & & $51.17 \%$ & $19.19 \%$ & $38.38 \%$ \\
\hline
\end{tabular}

Note: Solidarity Surcharge contained in income and corporation tax; municipal rate for local trade tax of $400 \%$

If an investor received 100 of dividends, the business profit, i.e. the economic income, was 175.57. One pays local trade tax (29.26) and corporation tax at a rate of $40 \%$ (plus solidarity surcharge) for retained earnings (61.74). When the profit is distributed, the corporate tax rate is lowered to $30 \%$ and a relief of 15.44 is granted in this case. The distribution (100) is subject to the personal income tax rate and solidarity surcharge at a tax base of 146.31 that is equal to the business profit after local trade tax. As the corporation tax is imputed at a rate of $30 \%$, the individual increases his consumable amount by 71.44 , implying a CNTR of $59.31 \%$. Applying the narrow focus, one neglects the presence of the local trade tax such that the income is equal to the income tax base (146.31). The result of this narrow focus is a CNTR (here $E T R^{B C S}$ ) of $51.17 \%$ which is well below the true tax burden on profits from incorporated businesses.

For profits that are taxed under the half income system, one pays local trade tax (27.16) and corporation tax at a rate of $25 \%$ plus solidary surcharge (35.82) on the tax base (135.82) where the local trade tax is deductible as a business expense and from its own tax base (162.99). The remainder (100) is distributed to owners immediately where half of the distribution is subject to personal income tax and solidarity surcharge (25.58). This procedure leaves owners with an after-tax increase in their wealth of 74.42 which translates into a CNTR of $54.34 \%$.

For the sake of our argument, let us assume that we only focus on the income tax and adjust the observed income tax base of dividend recipients (row 4 ) by $4 / 3$, as in BCS, p. 9 . On our adjusted gross income in row 1 we now slap the empirically observed income tax and solidarity surcharge (25.58) and calculate an $E T R^{B C S}$ of $19.19 \%$ or $38.38 \%$, depending on whether we adjust the distribution in row 4 (100) - as demonstrated in column 3 or the tax base (50), which is half the distribution, as in column 4. Proceeding in this 
fashion, BCS underestimate the CNTR by over 8 percentage points for the full imputation system and by 35.15 or 15.97 percentage points for the half income system, respectively, depending on the adjustment.

In a nutshell, BCS severely underestimate the CNTR of over half of the income components for the top $0.1 \%$ quantile and over $94 \%$ for the $0.001 \%$ quantile. Furthermore, the bias increases in 2002 as the share of dividends taxed under the half income system will be higher than in 2001 .

\subsubsection{Tax Treatment of Losses}

With regard to the tax treatment of losses, inter-temporal and intra-temporal offset measures must be distinguished. With regard to intra-temporal offsets, German tax law restricted the amount of losses that could be offset between the seven income types mentioned in $\S 2$ of the German Income Tax Code to 51,500 € for single filers and 103,000 $€$ for joint filers. Losses above this level were subject to a limited offset. $\mathrm{BCS}^{25}$ mention this source of complications but any adjustment mechanism remains undiscussed. The remaining losses should be factored into both the economic income and the tax liability. While the income adjustment is rather straightforward, the determination of tax liability assigned to the examined year cannot be conducted satisfactorily. One would need the present value of the tax liability reductions due to the remaining losses from the year under examination accruing in the future. Potentially, this assessment could stretch out into a very distant future if taxable income for the offset is slow to come by or if the carry-forward is sizable.

The restrictions only affect $0.05 \%$ of the taxpayers with a positive income but it should be noted that $0.55 \%$ of the top $1 \%$ quantile is affected with a mean of $3,374,415 €$, showing that the flaw in the calculation is more severe for the rich.

Inter-temporal offsets were limited to a carry-back to the previous year up to $511,500 €$ and unlimited carry-forwards. Bearing these legal rules in mind, the tax payments attributable to a single period must be adjusted. BCS' starting point for computing the adjusted gross income in $t$, the overall amount of income (Gesamtbetrag der Einkünfte), does not include the inter-temporal offsets. However, their measure of the assessed income tax liability in $t$, i.e. the nominator of $E T R_{t}^{B C S}$, is lowered by the inter-temporal loss deductions while the denominator - the AGI - remains constant. The reduction of the assessed income tax liability and the nominator, respectively, has to be attributed to the period when the loss occurred, i.e. to $t+1$ or $t-x$.

In a nutshell, the tax liability attributable to the examined period $t$ is the assessed income tax liability that would have been due without any inter-temporal loss offsets in $t$ but - as argued above - lowered by the present value of tax liability reductions from losses that occurred in $t$ but could not be offset in that period.

The following example gives an idea of the degree to which the omission of losses can bias the CNTR. Assume a (simplified) scenario with four single taxpayers where each investor has an overall amount of income of 5,000,000 $€$ in 2001. To steer clear of the complications of taxes other than the income tax, assume that his overall amount of income consists of wage income only. Investor 1 has neither loss carry-back nor carryforwards. Investor 2 suffers a loss of $1,000,000 €$ in 2002 , such that he can carry back $511,500 €$ to 2001 . Investor 3 has a loss carry-forward of $1,000,000 €$ which he fully

\footnotetext{
$\overline{{ }^{25} \text { Cf. footnote } 9 .}$
} 
offsets in 2001. Investor 4 features both a loss carry-forward of 1,000,000 $€$ and a loss of $1,000,000 €$ in 2002 that is carried back to 2001 to the tune of $511,500 €$. We now compute the assessed income tax liability for each investor in 2001 (row 5) and the tax payment assigned to 2001 (row 6). By dividing row 5 by the income in 2001, one arrives at $E T R^{B C S}$. Row 8 delivers the comprehensive nominal tax rate including the tax payment assigned to 2001 (CNTR $\left.R^{2001}\right)$.

Table 6. The Effect of Inter-temporal Offsets on the ETR

\begin{tabular}{llrrrr}
\hline & Investor & 1 & 2 & 3 & 4 \\
\hline$(1)$ & Income in 2001 & $5,000,000$ & $5,000,000$ & $5,000,000$ & $5,000,000$ \\
$(2)$ & Carryback & - & 511,500 & - & 511,500 \\
$(3)$ & Carryforward & - & - & $1,000,000$ & $1,000,000$ \\
$(4)$ & Taxable Income & $5,000,000$ & $4,488,500$ & $4,000,000$ & $3,488,500$ \\
\hline$(5)$ & Assessed Income & $2,537,359$ & $2,275,638$ & $2,025,684$ & $1,763,963$ \\
& Tax Liability & & & & \\
$(6)$ & Tax Payment & $2,537,359$ & $2,537,359$ & $2,537,359$ & $2,537,359$ \\
& assigned to 2001 & & & & \\
\hline$(7)=(5) /(1)$ & ETR $^{\text {BCS }}$ & $\mathbf{5 0 . 7 5 \%}$ & $\mathbf{4 5 . 5 1 \%}$ & $\mathbf{4 0 . 5 1 \%}$ & $\mathbf{3 5 . 2 8 \%}$ \\
$(8)=(6) /(1)$ & CNTR $^{\mathbf{2 0 0 1}}$ & $\mathbf{5 0 . 7 5 \%}$ & $\mathbf{5 0 . 7 5 \%}$ & $\mathbf{5 0 . 7 5 \%}$ & $\mathbf{5 0 . 7 5 \%}$ \\
\hline
\end{tabular}

${ }^{1}$ Solidarity Surcharge contained in income tax payment

While each investor receives the same income in 2001, $E T R^{B C S}$ varies from $35.28 \%$ to $50.75 \%$ while the $C N T R^{2001}$ is actually $50.75 \%$ for all four investors. If one raised the loss carryforward for investor $4, E T R^{B C S}$ would drop further. The intertemporal loss offset lowers the assessed income tax liability while the income of 2001 is not touched upon. But the reduction of the income tax liability cannot be assigned to 2001 since the losses and the tax reduction must be assigned to the period when the loss occurred. What this paragraph shows is that it is virtually impossible to disentangle taxpayers' tax affairs and focus on a single year to assess the cut that taxation takes out of their income.

With regard to the importance of this issue, the inter-temporal loss offset affects $1.38 \%$ of all taxpayers, this proportion rises to $9.38 \%(13.12 \% / 13.31 \%)$ for the top $0.1 \%(0.01 \%$ $/ 0.001 \%$ ) quantile with a mean of $1,200,810 €(3,630,884 € / 9,019,291 €)^{26}$, implying that the underestimation bias is not uniformly distributed among the taxpayers. It rather serves to reinforce the impression that the rich are not paying taxes.

\subsubsection{Income from renting and leasing}

A hazy subject in BCS is the treatment of income from renting and leasing. According to BCS, "losses from renting and leasing exceeding some thresholds (are disregarded) since most of these losses are likely to arise from tax avoidance." ${ }^{27}$ Even disregarding the status of the term "tax avoidance" (which is customarily used to denote perfectly legal minimization strategies of one's tax liability, as opposed to criminal "tax evasion"),

\footnotetext{
$\overline{26}$ Cf. table 12.

27 BCS, p. 23. The threshold is set equal to $2,500 € / 5,000 €$.
} 
and the reasoning provided, the asymmetric truncation of losses from renting and leasing strikes one as arbitrary.

BCS dwell on this income type extensively and suspect major loopholes for the rich there. According to the calculations by Müller (2004, p. 77), income from renting and leasing plays a minor, yet special role in that aggregate income tax revenue from this income type has been consistently negative over the years. With regard to losses from this income type, Müller (2004, p. 93) goes on to argue that these are concentrated in the upper quantiles of the German income distribution. Our analyses show ${ }^{28}$ that $18.05 \%$ of all taxpayers report earnings from renting and leasing. Among these taxpayers, $52.01 \%$ report losses. This explains the negative share of $-0.14 \%$ of the income from renting and leasing in the overall amount of income. It has to be noted, though, that $1,652,865$ taxpayers (32,48\% of the reported cases) report losses exceeding 5,000 $€$ such that the truncation envisioned by BCS becomes relevant. The effects of this - arbitrary threshold of 5,000 $€$ on the calculations in BCS are easily explained: the truncation cuts off the lower tail of the distribution of income from rent and leasing, which - artificially - increases the mean income from this income type from $-687 €$ to $4.604 €$. Müller (2004, p. 92, Fig. 2.2) draws attention to the extremely uneven distribution of losses from renting and leasing for the years 1989, 1992 and 1995. The $90 \%$ of taxpayers with the lowest overall amount of income in the respective year declared less than $60 \%$ of the entire amount of losses accrued in this income type, while the remaining right tail of the income distribution declared the missing 40 odd $\%$.

Apart from the arbitrary truncation of losses (which we undo in our calculations in subsection 3.2), several problems aggravate the calculations envisioned by BCS. Firstly, it should be borne in mind that real estate management can also be conducted in an unincorporated or incorporated business, making any truncation impossible. Furthermore, any gains or losses from the divestment of real estate would be subject to corporate and personal taxation. Secondly, the data only record the current returns and deductions, but exclude any gains or losses realized upon sale of the real estate itself in the income from renting and leasing. These would show up in the income type "other income" only if the sale took place within the speculation period ${ }^{29}$. Since an investor includes both the returns from renting and the resale price in his calculus, it is impossible to separate the income from renting and leasing and the attendant gains and losses from sale. The datasets available for Germany do not allow one to make this connection, though.

With regard to the returns to renting and leasing, the state of the German real estate market is not easily ascertainable. As is true of any real estate market, transactions are infrequent and the terms of these transactions are rarely released. Recent years have witnessed the first concerted efforts toward the compilation of a price index for real estate in Germany. Hoffmann and Lorenz (2006, p. 30-36) report several indicators of price developments for German real estate. While the multitude of indicators reported there do not give a consistent picture, they certainly refute the notion that outsized gains could be realized in German real estate in the last two decades. Indeed, government had to stimulate real estate investments in East Germany to entice investors at the beginning of the 1990s, where faster depreciation for tax purposes was one of the main instruments. As the diagrams in Hoffmann and Lorenz (2006, p. 33) show, prices for East German real

\footnotetext{
$\overline{28 \text { Cf. table } 10 .}$

29 Cf. our example in table 2.
} 
estate declined precipitously during the period 1995 to 2005. Given that large-scale pretax gains obviously did not materialise, the claim that income from renting and leasing has been a "a vast loophole for tax-saving activities in Germany for decades, especially in the 1990s "30" rings hollow ${ }^{31}$.

So far, we can conclude that not only the measure of effective taxation itself is disputable but also the definition of the income does not strictly follow any of the three concepts presented in section 2.3. As BCS also omitted the local trade tax, the corporate tax, the inter-temporal effects of loss deduction in their computation and regarded economic losses from renting and leasing as "tax avoidance", the numerator - the taxes paid - as well as the denominator - the income - are strongly biased. Furthermore, the quotient of these (biased) numbers cannot be interpreted as a measurement of effective taxation, at the utmost as a nominal tax burden in one year.

\section{Analysis of Effective Tax Rates on Top Incomes}

\subsection{Description of Available Datasets}

BCS describe the components of their dataset and their matching procedure quite extensively in their chapter 3. The dataset used in BCS is a sample composed of matched information from the SOEP and the FAST 1992-2001: To overcome deficiencies in each of the two datasets, BCS lump them together to form their "integrated ITR-SOEP data set". The matching algorithm employed is described in Bach et al. (2007, Appendix 2).

Their first component, the FAST ${ }^{32}$ is comprehensively described in Merz et al. (2006). It is a scientific use file that is collected every three years and contains a $10 \%$ random sample of tax returns filed in the respective year, resulting in approximately 3,000,000 cases out of a population of approximately 30,000,000 tax returns. So far - as of the time of writing - the data for the years 1992, 1995, 1998 and 2001 have been made available. As a stratified sample, this file contains very precise information for certain minority groups of the population whose data are consequently anonymised more strongly. In particular, the right tail of the income distribution is entirely present in the dataset. Overall, more than 600 variables are contained in the dataset.

The time structure suggested by the triennial compilation process for the FAST does not imply a panel structure, though. Crucially for the analysis in BCS and ours, the concatenation of the four yearly files does not allow one to track taxpayers across time. As an anonymised and randomised file, information cannot be linked across years. Assessments of tax burdens are thus only possible for a given individual taxpayer and year.

As an additional crucial hurdle, German Income tax law stipulates the taxation of accounting profits for certain income types, i.e. income from forestry and agriculture, income from business activity and self-employment. The process of the determination of taxable profit is not observable in the data whereas the resulting balance is reported. This contrasts with the other income types where the determination of their contribution to the tax base is observable in much greater depth. As a corollary, the presence or absence of accruals within the reported profits cannot be determined. Any attempt to undo their

\footnotetext{
${ }^{30}$ Emphasis added by the authors.

${ }^{31}$ We report empirical results for gains/losses from real estate transactions in table 13.

32 Abbreviation of the German "Faktische Anonymisierung der Steuerstatistik" - De Facto Anonymisation of the Tax Statistics.
} 
effects is thus doomed.

Regarding the second major data source for BCS, comprehensive information on the German Socio-Economic Panel, SOEP, compiled by the DIW, Berlin, can be found in Haisken-DeNew and Frick (2005, p. 16): "The SOEP was started in 1984 as a longitudinal survey of private households and persons in the Federal Republic of Germany. The central aim of this panel study is to collect representative micro-data on persons, households and families...". It is designed as a yearly sample of the same units (households and individuals) and thus does allow inference with panel methods. Compared with the FAST samples, the size of the dataset is more modest, varying between 10,000 and 25,000 due to the addition of several new subsamples ${ }^{33}$. On the other hand, the SOEP sample contains a broader cross-section of individuals as it also contains taxpayers who are not legally obliged to file tax returns. With regard to tax variables, it is quite apparent that the SOEP is not designed with the tax researcher in mind and that the tax environment of the respondents must be inferred in a rather piecemeal fashion and with a relatively high degree of uncertainty ${ }^{34}$.

Admittedly, a match with the SOEP could theoretically provide a tentative link across years which might yield a panel structure. Yet the reasoning for the matching provided in BCS, p. 6/7 does not mention the panel structure, but is explicitly intended to more accurately reflect conditions in the lower tail of the income distribution.

We tried to replicate this particular dataset as far as possible. Our contract with the provider of the FAST sample did not allow us to match with another data source, though. Consequently, we could not work on the same data. Given the high degree of anonymisation in the right tail of the income distribution prevailing in the FAST dataset, we ran a controlled data retrieval under the supervision of the statistical office which gave us access to the entire population of almost 30,000,000 tax returns (ITR) in Germany in 2001 and 900 variables for each of those ${ }^{35}$.

The deficiency of the missing matching is mitigated because we emphasize the conditions in the right tail of the German Income distribution. As this particular subgroup, the "target group", is completely represented in our dataset, we can make inferences largely unperturbed by the missing cases for the left tail of the income distribution. Given that our (and BCS') main interest lies in the right tail, we can omit the matching from our analysis $^{36}$.

\section{2. "Adjusted Gross Income" Variable in BCS}

BCS devote their section 4 and appendix 2 to the derivation of an "adjusted gross income". We argue above ${ }^{37}$ that any attempt to measure the economic profit from the data available to researchers is severely restricted. Bearing the limitations in mind, we provide our digest for the derivation of an economically based single-period income. Table 7 displays

\footnotetext{
33 Cf. Haisken-DeNew and Frick (2005, p. 26).

$34 \mathrm{Cf}$. Wagenhals and Buck (2007) for a possible solution.

35 Data handling issues forced us to drop taxpayers with a reported overall amount of income around $0 €$. This induced a drop in the sample size to approximately $28,150,000$.

${ }^{36}$ In any case, the link thus established would be too flimsy as the small number of 25,000 units in the SOEP has to be matched to the approximately 3,000,000/30,000,000 units in the FAST/ITR. On average, each SOEP unit must account for well over 100/1,000 units in the FAST/ITR database.

37 Cf. section 2.4 on page 6 .
} 
our adjustments compared to the adjustments by BCS, grouped by the seven income types recognized under German income tax law. We highlight major deviations from the methodology in BCS in bold face.

Table 7. Definition of Adjusted Gross Income

\begin{tabular}{|c|c|c|}
\hline $\begin{array}{l}\text { Income } \\
\text { from }\end{array}$ & Adjustments made by BCS & $\begin{array}{l}\text { Necessary adjustments of the } \\
\text { taxable income }\end{array}$ \\
\hline Wages & $\begin{array}{l}\text { - Adjustment for employers' } \\
\text { social security contributions } \\
\text { - Allowable expenses excluded } \\
\text { - Social security contributions } \\
\text { for civil servants imputed } \\
\text { - Tax exempt foreign wage } \\
\text { income added }\end{array}$ & $\begin{array}{l}\text { - Adjustment for employers' } \\
\text { - Allocial security contributions } \\
\text { - Allowable expenses included } \\
\text { - Social security contributions } \\
\text { for civil servants imputed } \\
\text { - Tax exempt foreign wage } \\
\text { income added }\end{array}$ \\
\hline $\begin{array}{l}\text { Business } \\
\text { Activity }\end{array}$ & $\begin{array}{l}\text { - Includes income from } \\
\text { agriculture and forestry, from } \\
\text { unincorporated business } \\
\text { enterprise and from } \\
\text { self-employed activities } \\
\text { - Tax exempt profits from } \\
\text { outbound business activities } \\
\text { included } \\
\text { - Tax subsidies added } \\
\text { - Income should be adjusted for } \\
\text { "tax expenditures" such as } \\
\text { depreciation, but data is not } \\
\text { available }\end{array}$ & $\begin{array}{l}\text { - Includes income from } \\
\text { agriculture and forestry, from } \\
\text { unincorporated business } \\
\text { enterprise and from } \\
\text { self-employed activities } \\
\text { - Tax exempt profits from } \\
\text { outbound business activities } \\
\text { included } \\
\text { - Tax subsidies added } \\
\text { - Since these "tax } \\
\text { expenditures" are "capital } \\
\text { expenditures", an } \\
\text { adjustment cannot be } \\
\text { justified } \\
\text { - Local trade tax added for } \\
\text { unincorporated business }\end{array}$ \\
\hline $\begin{array}{l}\text { Capital } \\
\text { Gains }\end{array}$ & $\begin{array}{l}\text { - Includes gains from disposal } \\
\text { of enterprises or substantial } \\
\text { shareholdings (Income from } \\
\text { business activity) and of } \\
\text { private investments } \\
\text { (Speculation gains } \S 23 \text { ) }\end{array}$ & $\begin{array}{l}\text { - Includes gains from disposal } \\
\text { of enterprises or substainal } \\
\text { shareholdings (Income from } \\
\text { business activity) and of } \\
\text { private investments } \\
\text { (Speculation gains } \S 23 \text { ) } \\
\text { - "Tax-Free" capital gains are } \\
\text { added, as far as reported }\end{array}$ \\
\hline
\end{tabular}


Table 7. Definition of Adjusted Gross Income

\begin{tabular}{|c|c|c|}
\hline $\begin{array}{l}\text { Income } \\
\text { from }\end{array}$ & Adjustments made by BCS & $\begin{array}{l}\text { Necessary adjustments of the } \\
\text { taxable income }\end{array}$ \\
\hline $\begin{array}{l}\text { Interest } \\
\text { and } \\
\text { Dividends }\end{array}$ & $\begin{array}{l}\text { - Saver Allowance added to } \\
\text { income } \\
\text { - Recorded net dividend is } \\
\text { multiplied by } \frac{4}{3}\end{array}$ & $\begin{array}{l}\text { - Saver Allowance added to } \\
\text { income } \\
\text { - Recorded net dividend under } \\
\text { half income system is } \\
\text { adjusted by corporate tax } \\
\text { and by the local trade tax } \\
\text { - Dividends under full } \\
\text { imputation systems are } \\
\text { adjusted by local trade } \\
\text { tax }\end{array}$ \\
\hline $\begin{array}{l}\text { Renting } \\
\text { and } \\
\text { Leasing }\end{array}$ & $\begin{array}{l}\text { - Losses exceeding } 5,000 € \text { are } \\
\text { ignored } \\
\text { - Losses from shareholdings of } \\
\text { closed property funds, etc. } \\
\text { exceeding } 2,500 € \text { are ignored }\end{array}$ & $\begin{array}{l}\text { - Losses are fully included in } \\
\text { income }\end{array}$ \\
\hline $\begin{array}{l}\text { Transfer } \\
\text { Income }\end{array}$ & $\begin{array}{l}\text { - Corrected for the allowance } \\
\text { for taxable pensions from } \\
\text { employment } \\
\text { - Non-taxable share of life } \\
\text { annuity funds is added to } \\
\text { income ( } 70 \% \text { of the pension) } \\
\text { - Social assistance, housing } \\
\text { benefits and other public } \\
\text { transfers are taken from the } \\
\text { SOEP }\end{array}$ & $\begin{array}{l}\text { - Corrected for the allowance } \\
\text { for taxable pensions from } \\
\text { employment } \\
\text { - Non-taxable share of life } \\
\text { annuity funds is not added } \\
\text { to income } \\
\text { - Social assistance, housing } \\
\text { benefits and other public } \\
\text { transfers are ignored since } \\
\text { top } 1 \% \text { are unlikely to receive } \\
\text { public transfer income }\end{array}$ \\
\hline Losses & & $\begin{array}{l}\text { - Remaining non-deducted } \\
\text { losses occurred in } 2001 \\
\text { should be subtracted. }\end{array}$ \\
\hline
\end{tabular}

We include the deductible expenses for income from wages, i.e. we do not add these expenses to the adjusted gross income since for example the costs for training or education dilute the taxpayer's economic income while also being recognized as tax deductible. Adding these costs would lead to an overestimation of the adjusted gross income and, consequently, to an underestimation of the nominal tax burden.

BCS describe a category "business activity" that bundles the profit income types recognized under German income tax law. Firstly, a line must be drawn between the income from unincorporated businesses and income from self-employment: The local trade tax burden is added to the taxable income as shown in table 4 for unincorporated business, while the self-employed are not subject to this tax. As BCS omit the local trade tax entirely, this problem does not crop up in their contribution. Secondly, any - putative - adjustments for "tax expenditures" cannot be justified. BCS term the provisions for 
pension reserves or depreciation charges "tax expenditures", without properly explaining the implications of this classification. From circumstantial evidence, it seems that any "accruals", i.e. charges that do not coincide with the associated cash flow, are regarded as "in need of correction". Adding these components to the taxable income would imply a fundamental flaw since the tax expenditures either have already been capital expenditures - as in the case of depreciation allowances - or will be wage expenditures in the future in the case of pension reserves. As mentioned in subsection 3.1, the profit- and loss statements of the tax balance sheets underlying the income from unincorporated businesses is not available. Thus, the ability to correct for supposed "loopholes" is restricted by data availability.

The capital gains from the sale of an enterprise or a substantial shareholding - even if they are tax-exempted - are added to the speculation gains to form the income from capital gains. The gains realized from the disposal outside the speculative period are not included in the taxable income effectuating an underestimation of the adjusted gross income from capital gains. These gains must be added to the adjusted gross income but unfortunately they are not observable ${ }^{38}$. It has to be noted that the "tax-free" capital gains are far away from being tax-free. Many studies proved that corporate and dividend taxes reduce the valuation of shares. Thus, the so called "tax-free" capital gains are already taxed at the corporate and the shareholder level ${ }^{39}$.

The income from interest and dividends represents another major source of error in the BCS approach. Firstly, the bundling of this income stream ties together two heterogeneous sources of income, with dividends carrying a burden from the corporate level while interest is unencumbered by any prior taxation. While BCS multiply the recorded net dividend by the factor 1.333 in order to try to account for the corporation tax under the half income system, they ignore the local trade tax as shown in table 5 for both the half income system and the full imputation system. Therefore, we adjust the taxable dividend by adding the local trade tax. Additionally we add the corporation tax under the half income system. Consistent with BCS, we add the saver allowance to the income.

For the reasons discussed in subsection 2.5.3, we do not adjust the income from renting and leasing. The consistently negative income that renting and leasing has delivered over the last decades indicates that investors suffered economic losses. Furthermore, we do not go along with the practice in BCS of truncating losses for this particular income type at a threshold of $5,000 €$.

We do not match the ITR data and the SOEP datasets, hence in the case of transfer income, we cannot account for social assistance, housing benefits or other public transfers. This biases the income generally downwards but the effect for the top incomes is negligible since they are not likely to receive any kind of transfer. In contrast to BCS, we do not add

\footnotetext{
38 Since the "tax-free" speculation gains are neither reported in the ITR data nor in the SOEP, any matching process does not help to uncover this flaw. With the introduction of the final withholding tax in 2009, capital gains from the disposal of shares will be taxed with $25 \%$ regardless of the holding period solving the information problem behind the "tax-free" capital gains.

But, we assume the speculation gains to have minor impact on the income in 2001 and 2002, since the substantial interest for tax purposes was lowered to $1 \%$ in 1999 . Furthermore, the stock market showed rather bad performance in 2001 where the TecDax crashed from over 9,500 points in 2000 to a minimum 683.82 in 2001 and the DAX fell to its 1998 level.

39 See among others Ball (1984) and Collins and Kemsley (2000).
} 
the non-taxable share of life-annuity funds which we regard as a payback of contributions made.

Finally, losses occurred in 2001 that could not have been offset against other (positive) sources of income are not integrated in the overall amount of income and thus, should be recognized in the computation of the economic income. However, as the present value of tax liability reduction from the remaining losses is not observable, one cannot correctly account for the inter-temporal effect of the restriction to the intra-temporal loss offset. Therefore, we cannot adjust for these losses and underestimate the "true" CNTR.

Bearing in mind that the "correct" and representative figure of income can only be derived from any cross-sectional dataset under the restrictions discussed in section 2.4, we conclude that our definition of income differs from the adjusted gross income in BCS for every income type.

\subsection{Adjustment for Taxes Paid}

In addition to the adjustments enumerated in table 7, we also adjust the numerator in equation (2) and account for the most important taxes. We detail these corrections in table 8 which itself mirrors table 7 .

Table 8. Adjustments to Recognized Tax Burden

\begin{tabular}{ll}
$\begin{array}{l}\text { Income } \\
\text { from }\end{array}$ & Necessary adjustments to Recognized Tax Burden \\
\hline Wages & • Accounted for possible taxes paid on foreign wages \\
\hline $\begin{array}{l}\text { Business } \\
\text { Activity }\end{array}$ & $\begin{array}{l}\text { - Taxes paid abroad on tax exempted profits from } \\
\text { outbound business activities included }\end{array}$ \\
\hline Interest & Local Trade Tax is added to the PIT \\
and & Corporate tax and the local trade tax are added to \\
Dividends & - Local trade tax added for the full imputation system \\
\hline & - Loss carry-forwards used in 2001 and carry-backs \\
& from 2002 lower recorded tax burden in 2001. \\
& $\begin{array}{l}\text { Difference in income tax burden with and without } \\
\text { carryforward and carryback is added. }\end{array}$ \\
Losses & Present value of tax reduction from non-deducted \\
& losses occurred in 2001 should lower tax liability. \\
\hline
\end{tabular}

The adjustment of the recognized tax burden follows a simple rule. If you increase the taxable income for any income type in order to derive economic income, you have to account for possible taxes paid on the respective levels. For example, BCS adjust for tax exempted foreign wages income. If these wages carry a tax burden from abroad then these taxes must be added to the PIT. The same problem results for tax exempted profits from outbound business activities with a potential accumulated tax burden. For the correct adjustment, information on the country of origin, the tax rate and the tax base would be necessary. 
For the case of capital gains, the problem of inferring the accumulated tax burden proves insurmountable. It is neither observable nor measurable with any method as one would have to compare the pre-tax capital gain with the (observable) after-tax capital gain. However, several studies prove that capital gains carry a tax burden, as discussed in the last section.

By contrast, the local trade $\operatorname{tax}\left(\tau^{L T T}\right)$ and the corporate tax $\left(\tau^{\text {Corp }}\right)$ paid on the corporate level can be derived from the information available from the ITR dataset. If an incorporated business paid out one Euro of dividends under the half income system, resp. full imputation system, then the profit on the corporate level was $\frac{1}{\left(1-\tau^{\text {Corp }}\right)\left(1-\tau^{L T T}\right)}$, resp. $\frac{1}{1-\tau^{L T T}}$. Since we adjusted the gross income, we have to adjust the recognized tax burden by the corporate tax and the local trade tax as well. The accumulated tax burden from dividend income on the corporate level $\left(A T B_{D i v}\right)$, which is added to the PIT and which is defined as the difference between the pre-corporate-tax profit and the pre-income-tax gross dividend, evolves under the half income system as

$$
A T B_{D i v}=\left(\tau^{C o r p}+\tau^{L T T}-\tau^{C o r p} \cdot \tau^{L T T}\right) \frac{\text { Div }}{\left(1-\tau^{C o r p}\right)\left(1-\tau^{L T T}\right)}
$$

and under the full imputation system respectively as

$$
A T B_{D i v}=\tau^{L T T} \frac{D i v}{1-\tau^{L T T}} .
$$

Additionally, the local trade tax must be added to the recognized tax burden if a taxpayer has income from an unincorporated business. We can observe the lumpsum offset of the local trade tax (Steuerermäßigung bei Einkünften aus Gewerbebetrieb) from $\S 35$ denoted as $O_{\S 35}$. Thus, we derive the taxable business income (GewerbesteuerMessbetrag) by dividing the offset by 1.8. The accumulated tax burden of the income from an unincorporated income $A T B_{\text {Uninc }}$ evolves as the product of the taxable business income and the municipal collection rate (Gewerbesteuer-Hebesatz) $C R_{i}{ }^{40}$.

$$
A T B_{U n i n c}=C R_{i} \frac{O_{\S 35}}{1.8}
$$

Losses carried forward to 2001 from prior years and/or losses carried back from 2002 into 2001 impact the tax liability due in 2001 yet leave the adjusted gross income untouched. A recognition of the tax reduction solely in 2001 would unduly bias the resulting tax rates downward. For the reasons expounded in subsection 2.5.2, we account for this effect in the manner described at the bottom of table 8 . The present value of the tax liability reduction from non-deducted losses occurred in 2001 should, but cannot be recognized for the reasons discussed in subsection 3.2.

Since taxable capital gains from the disposal of enterprises and substantial shareholdings, business activity and dividends represent the major part of the income of the rich and the super-rich, BCS' measure of "effective taxation" provides an incorrect, downward biased picture of the "tax burden" of the rich.

\footnotetext{
$\overline{40}$ The index $i$ indicates that we account for regional differences in the collection rate in 2001. The federal state of the taxpayer is known from the dataset which allows us to apply the average collection rate for the individual federal state.
} 


\subsection{Empirical Results}

In this section, we provide our results for the cross-section of income tax returns in Germany in 2001. Table 9 shows the mean comprehensive nominal tax rates emanating from our adjustments, conditional on the quantiles of the income distribution, and the corresponding numbers from BCS, table 4 . The last column gives the difference in percentage points between the two sets of results. Note that the adjustments in our approach and in BCS differ in the manner described in table 7 so that the allocation to quantiles may not coincide perfectly.

Table 9. Comparison of the Comprehensive Nominal Tax Rate and $E T R^{B C S}$ for 2001

\begin{tabular}{lrrr} 
Quantile & CNTR & ETR $^{\text {BCS }}$ & $\Delta=$ CNTR-ETR $^{\text {BCS }}$ \\
\hline Decile 1-5 & $3.60 \%$ & $2.90 \%$ & $0.70 \%$ \\
Decile 6-9 & $12.87 \%$ & $10.10 \%$ & $2.77 \%$ \\
Decile 10 & $23.27 \%$ & $21.90 \%$ & $1.37 \%$ \\
\hline Top 1\% & $37.21 \%$ & $33.40 \%$ & $3.81 \%$ \\
Top 0.1\% & $45.25 \%$ & $38.20 \%$ & $7.05 \%$ \\
Top 0.01\% & $48.05 \%$ & $38.70 \%$ & $9.35 \%$ \\
Top 0.001\% & $50.30 \%$ & $38.10 \%$ & $12.20 \%$ \\
Top 0.0001\% & $51.39 \%$ & $36.00 \%$ & $15.39 \%$ \\
\hline
\end{tabular}

Source: ITR 2001, own calculationss

Apparently, there is a broad agreement between the results. Within the top $1 \%$ quantile, the results diverge markedly, with the differences ranging from 3.81 percentage points for the $1 \%$ quantile to 15.39 percentage points for the top $0.0001 \%$ quantile. Given the focus on the taxation of "the rich" in BCS, this development acquires a lot of significance. As an explanation for the differences, we provide table 10 on page 24 which clearly shows the change in composition in the adjusted sum of income between the quantiles.

Taxpayers below the $90 \%$ quantile rely heavily on domestic wage income $(84.54 \%$ for the deciles 1-5 and $91.81 \%$ for the deciles 6-9 respectively) which is taxed in a cash flow manner, i.e. in an uncontroversial way which requires very few adjustments. Within the upper $1 \%$ quantile, though, the importance of wage income declines precipitously from $44.22 \%$ for the top $1 \%$ quantile to $0.27 \%$ for the top $0.0001 \%$ while business and capital income assume greater weight. Taxpayers in the top $0.001 \%(0.0001 \%)$ quantile generate $94.24 \%(99.99 \%)$ of their income from capital or business income. These are the income types where our criticsm of the BCS approach bites most heavily and where consequently the divergence is greatest.

These results cast grave doubt on the validity of the claim in BCS, p. 17 that "...average effective tax rates paid by the economic elite..." was $38.1 \%$ in 2001 . The economic elite defined in BCS as the upper $0.001 \%$ quantile - actually faced a CNTR of $50.30 \%$ which is over 12 percentage points higher. Bearing all the caveats of our prior analysis in mind, the CNTRs exceed the top statutory income tax rates by several percentage points across the board, highlighting the influence of the local trade tax and the corporation tax on 
the overall tax burden. On top of that, the relevance of inter-temporal loss deductions, depicted in table 12 on page 25, increases with the quantiles, so that the bias arising from the omission of the losses in BCS also increases.

\subsection{Limitations}

Concerning the methodology used, we describe additional ${ }^{41}$ limitations in this section. As mentioned above, our main interest lies in the right tail of the income distribution. Note here that we must contend with the fact that the dataset only contains information pertaining to taxation. The definition of "income rich" should thus be read as "taxable income rich", subject to the modifications that we describe in table 7. Assume, in the fashion of table 1 on page 5, a taxpayer who makes spectacular gains in real estate and shares after the expiration of the speculation period of 10, resp. 1 year: if you further assume that this is his major source of income, he could make millions without the ITR dataset even noticing him. The particular definition of income dictated by German income tax law would effectively allow him to "fly below the radar". Similarly, if a taxpayer's assets consisted of a share in an incorporated business and the business retained its entire earnings for 2001, the taxpayer would be classified as "poor" in the 2001 cross-section because he does not have taxable income ${ }^{42}$ in this year. Note how differently this issue would be handled under economic income: if the investments enabled by the retention were profitable, an economic appreciation would be due, generating economic income in the year 2001. Given the inevitable departures of a cross-sectional income definition in the dataset from economic income stressed throughout our article, the classification of taxpayers into quantiles based on the "overall amount of income" (Gesamtbetrag der Einkünfte) is certainly problematic. These problems are shared with BCS and anyone who makes inferences from tax data.

\section{Conclusion}

We have provided a comprehensive examination of the most salient and controversial results in Bach et al. (2008). Our argumentation rests on several layers of critique:

Very fundamentally, we argue that a restriction on the income tax burden has lowered the "effective tax rates" calculated in BCS by up to 12 percentage points. We replace it with a comprehensive measure of tax burden and calculate tax rates that are well above the nominal tax rate. In particular, the omission of the local trade tax and the corporation tax from the calculations is bound to yield a skewed picture of the nominal tax burden. Given that income from business activity is concentrated in the upper quantiles of the income distribution, this omission does not cause a downward shift across all taxpayers, but an unambiguous bias toward lighter taxation of the rich. We also find that the concept of effective tax rates is not applicable, as the very notion of ETRs precludes their meaningful deployment in a single period calculus. Furthermore, we have questioned the role of accruals for tax purposes. By their very nature, these items must be interpreted in an inter-temporal perspective, as they are designed to transform cash flows into tax

\footnotetext{
41 Note that the main criticism of the BCS approach is contained in section 2.

42 This is true for the purposes of income taxation. Corporation tax is due on the profit, anyway. There is no link, though, in the data that would enable us to establish a connection.
} 
bases over time. We also find substantial shortcomings with respect to the treatment of tax losses, as inter-temporal aspects reassert themselves.

Reassuringly, the official tax statistics (Federal Ministry of Finance, 2001, p. 21) for 2001 provide a glimpse at the massive contribution that the income rich make toward income tax receipts: while the upper $50 \%$ of German income taxpayers contributed over $90 \%$ of income tax receipts in 2001, the upper ten percent contribute over $50 \%$ and the upper five percent, the smallest quantile for which these numbers are available for 2001, chips in 40 odd \%.

We have shown that the complaint in BCS, p. 20: “... effective tax progression stops at income levels within the top percentile, i.e. the effective tax rate is not monotonically increasing in gross income within the top percentile of the income distribution" is unsubstantiated and disregards elementary rules for measuring effective tax rates. 


\section{Additional Tables}

Table 10. Adjusted Income Components As Percentage of Adjusted Sum of Incomes

\begin{tabular}{|c|c|c|c|c|c|c|c|c|c|c|c|}
\hline \multirow[b]{2}{*}{ Quantiles } & \multicolumn{11}{|c|}{ Income from: } \\
\hline & $\S 13^{1}$ & $\S 15^{2}$ & $C G^{3}$ & $\S 18^{4}$ & $C G^{5}$ & $\S 19^{6}$ & $\S 20^{7}$ & $\S 21^{8}$ & $\S \mathbf{2 2}^{9}$ & $C G^{10}$ & Total \\
\hline Losses & 2.99 & 42.27 & 1.34 & 7.53 & 0.37 & 29.81 & 5.84 & 17.53 & -5.97 & 7.42 & 100 \\
\hline Decile $1-5$ & 0.66 & 3.77 & 0.10 & 1.67 & 0.01 & 84.54 & 3.16 & -0.05 & 6.23 & -0.05 & 100 \\
\hline Decile 6-9 & 0.65 & 3.91 & 0.08 & 1.60 & 0.01 & 91.81 & 1.45 & -0.18 & 0.75 & -0.02 & 100 \\
\hline Decile 10 & 0.73 & 8.29 & 0.46 & 9.14 & 0.13 & 78.03 & 3.66 & -0.40 & 0.49 & -0.08 & 100 \\
\hline Top $1 \%$ & 0.82 & 17.89 & 2.50 & 24.63 & 0.55 & 44.22 & 12.31 & -0.79 & 0.72 & -0.44 & 100 \\
\hline Top $0.1 \%$ & 0.75 & 37.83 & 5.75 & 12.75 & 0.75 & 25.09 & 21.22 & 0.63 & 1.46 & 0.36 & 100 \\
\hline Top $0.01 \%$ & 0.36 & 58.34 & 12.11 & 2.81 & 0.25 & 10.79 & 27.71 & -2.12 & 1.89 & -0.20 & 100 \\
\hline Top $0.001 \%$ & 0.00 & 68.84 & 11.36 & 1.64 & 0.00 & 3.04 & 25.40 & 0.51 & 0.58 & 0.18 & 100 \\
\hline Top $0.0001 \%$ & -0.02 & 78.66 & 3.89 & 0.06 & 0.00 & 0.27 & 21.33 & -0.30 & 0.00 & -0.43 & 100 \\
\hline Total & 0.66 & 4.23 & 0.13 & 2.37 & 0.02 & 85.89 & 2.50 & -0.14 & 3.43 & -0.04 & 100 \\
\hline
\end{tabular}

Source: ITR 2001, own calculations.

${ }^{1}$ Income from Agriculture and Forestry $-{ }^{2}$ Income from Unincorporated Business $-{ }^{3}$ Capital Gains from $\S 16$ and 17 (included in $\left.{ }^{2}\right)-{ }^{4}$ Income from Self-Employment $-{ }^{5}$ Capital Gains from $\S 18$ (included in ${ }^{4}$ ) ${ }^{6}$ Income from Wages $-{ }^{7}$ Income from Capital Income $-{ }^{8}$ Income from Renting and Leasing $-{ }^{9}$ Other Income $-{ }^{10}$ Speculation Gains (included in ${ }^{9}$ )

Table 11. Distribution of Adjusted Income Components among Quantiles

\begin{tabular}{|c|c|c|c|c|c|c|c|c|c|c|c|}
\hline \multirow[b]{2}{*}{ Quantiles } & \multicolumn{11}{|c|}{ Income from: } \\
\hline & $\S 13^{1}$ & $\S 15^{2}$ & $C G^{3}$ & $\S 18^{4}$ & $C G^{5}$ & $\S 19^{6}$ & $\S 20^{7}$ & $\S 21^{8}$ & $\S 22^{9}$ & $C G^{10}$ & SoI \\
\hline Losses & -1.02 & -4.49 & 1.14 & -0.43 & 0.50 & 0.15 & 0.52 & 61.74 & 0.97 & 4.15 & -0.32 \\
\hline Decile $1-5$ & 24.80 & 11.73 & 7.89 & 5.73 & 5.38 & 23.35 & 19.02 & $-17.73^{*}$ & 68.37 & 17.19 & 22.43 \\
\hline Decile 6-9 & 43.83 & 24.95 & 8.64 & 16.16 & 10.76 & 51.36 & 19.91 & 42.33 & 20.39 & 21.78 & 46.36 \\
\hline Decile 10 & 32.38 & 67.81 & 82.32 & 78.54 & 83.37 & 25.13 & 60.55 & 13.66 & 10.28 & 56.88 & 31.53 \\
\hline Top $1 \%$ & 9.88 & 44.09 & 71.29 & 39.49 & 57.75 & 4.15 & 42.85 & $-21.19^{*}$ & 4.04 & 40.87 & 9.94 \\
\hline Top $0.1 \%$ & 3.08 & 29.42 & 54.66 & 6.95 & 21.03 & 0.89 & 25.43 & $-14.37^{*}$ & 1.76 & 21.71 & 4.07 \\
\hline Top $0.01 \%$ & 0.49 & 15.90 & 33.03 & 0.69 & 2.22 & 0.16 & 11.23 & $-1.53^{*}$ & 0.77 & 1.95 & 1.69 \\
\hline Top $0.001 \%$ & -0.01 & 6.32 & 9.23 & 0.13 & 0.02 & 0.02 & 4.26 & $-0.58^{*}$ & 0.27 & $-2.86^{*}$ & 0.62 \\
\hline Top $0.0001 \%$ & 0.00 & 1.79 & 0.89 & 0.00 & 0.00 & 0.00 & 1.07 & 0.21 & 0.00 & 1.25 & 0.16 \\
\hline Total & 100 & 100 & 100 & 100 & 100 & 100 & 100 & 100 & 100 & 100 & 100 \\
\hline
\end{tabular}

Source: ITR 2001, own calculations.

${ }^{1}$ Income from Agriculture and Forestry $-{ }^{2}$ Income from Unincorporated Business $-{ }^{3}$ Capital Gains from $\S 16$ and 17 (included in ${ }^{2}$ ) $-{ }^{4}$ Income from Self-Employment $-{ }^{5}$ Capital Gains from $\S 18$ (included in $\left.{ }^{4}\right)^{6}$ Income from Wages -

${ }^{7}$ Income from Capital Income $-{ }^{8}$ Income from Renting and Leasing $-{ }^{9}$ Other Income $-{ }^{10}$ Speculation Gains (included in ${ }^{9}$ ) - ${ }^{*}$ Negative percentage indicates positive income since overall income from renting and leasing and from speculation gains respectively is negative. 
Table 12. Relevance of Inter-temporal Loss Deductions

\begin{tabular}{lrrrrrr}
\hline & RL $\S 2^{1}$ & \multicolumn{3}{c}{ Inter-temporal LD } & & Total $^{3}$ \\
Quantiles & & Total & \multicolumn{1}{c}{ Mean (€) } & \multicolumn{1}{c}{ CB } & \multicolumn{1}{c}{ CF } & \\
\hline Losses & $99.51 \%$ & $0.09 \%$ & $19,894.51$ & $0.00 \%$ & $0.09 \%$ & $99.51 \%$ \\
\hline Decile 1-5 & $0.04 \%$ & $1.90 \%$ & $10,809.46$ & $0.22 \%$ & $1.69 \%$ & $4.01 \%$ \\
Decile 6-9 & $0.03 \%$ & $0.71 \%$ & $37,038.94$ & $0.18 \%$ & $0.53 \%$ & $0.74 \%$ \\
Decile 10 & $0.16 \%$ & $1.57 \%$ & $187,327.72$ & $0.44 \%$ & $1.16 \%$ & $1.06 \%$ \\
\hline $1 \%$ & $0.55 \%$ & $4.83 \%$ & $415,176.84$ & $1.34 \%$ & $3.65 \%$ & $5.23 \%$ \\
$0.1 \%$ & $0.71 \%$ & $9.38 \%$ & $1,200,816.34$ & $2.84 \%$ & $7.03 \%$ & $9.86 \%$ \\
$0.01 \%$ & $0.72 \%$ & $13.12 \%$ & $3,630,884.23$ & $4.02 \%$ & $9.97 \%$ & $13.66 \%$ \\
$0.001 \%$ & $0.00 \%$ & $13.31 \%$ & $9,019,291.05$ & $3.60 \%$ & $11.15 \%$ & $13.67 \%$ \\
$0.0001 \%$ & $0.00 \%$ & $22.22 \%$ & $9,092,094.67$ & $3.70 \%$ & $18.52 \%$ & $22.22 \%$ \\
\hline Total & $\mathbf{1 . 0 9 \%}$ & $\mathbf{1 . 3 8 \%}$ & $36,062,25$ & $\mathbf{0 . 2 3 \%}$ & $\mathbf{1 . 1 6 \%}$ & $\mathbf{2 . 4 6 \%}$ \\
\hline 1
\end{tabular}

${ }^{1}$ Percentage of taxpayers with remaining non-deducted intratemporal losses of 2001 (§ 2 German Tax Code) $-{ }^{2}$ Percentage of taxpayers with intertemporal loss deductions in 2001. Total percentage and proportion of carrybacks from $2002(\mathrm{CB})$ and all carryforwards from prior years reported -

${ }^{3}$ Cumulates the cases, where the CNTR is biased either due to a remaining non-deducted intratemporal loss or an intertemporal loss offset as percentage of all taxpayers. 
Table 13. Reporting Frequency of Income Components

\begin{tabular}{|c|c|c|c|c|c|c|c|}
\hline \multirow[b]{2}{*}{ Quantiles } & \multicolumn{7}{|c|}{ Income from: } \\
\hline & $\S 13^{1}$ & $\S 15^{2}$ & $\S 18^{3}$ & $\S 19^{4}$ & $\S 20^{5}$ & $\S 21^{6}$ & $\S 22 / 23^{7}$ \\
\hline Losses & $3.97 \%$ & $58.18 \%$ & $11.10 \%$ & $28.09 \%$ & $12.42 \%$ & $41.47 \%$ & $17.68 \%$ \\
\hline Decile 1-5 & $1.87 \%$ & $12.49 \%$ & $3.46 \%$ & $82.09 \%$ & $9.40 \%$ & $12.73 \%$ & $21.51 \%$ \\
\hline Decile 6-9 & $2.27 \%$ & $12.71 \%$ & $5.39 \%$ & $94.82 \%$ & $9.46 \%$ & $18.84 \%$ & $8.38 \%$ \\
\hline Decile 10 & $2.13 \%$ & $25.28 \%$ & $20.21 \%$ & $89.32 \%$ & $26.59 \%$ & $42.11 \%$ & $7.80 \%$ \\
\hline Top 1\% & $2.80 \%$ & $53.36 \%$ & $38.96 \%$ & $75.15 \%$ & $65.09 \%$ & $72.57 \%$ & $15.79 \%$ \\
\hline Top $0.1 \%$ & $4.27 \%$ & $75.45 \%$ & $32.63 \%$ & $69.62 \%$ & $89.07 \%$ & $82.65 \%$ & $23.50 \%$ \\
\hline Top $0.01 \%$ & $6.99 \%$ & $89.46 \%$ & $32.52 \%$ & $63.32 \%$ & $94.69 \%$ & $86.05 \%$ & $27.50 \%$ \\
\hline Top $0.001 \%$ & $10.07 \%$ & $94.96 \%$ & $46.40 \%$ & $58.99 \%$ & $95.32 \%$ & $87.05 \%$ & $35.97 \%$ \\
\hline Top $0.0001 \%$ & $14.81 \%$ & $96.30 \%$ & $62.96 \%$ & $62.96 \%$ & $96.30 \%$ & $85.19 \%$ & $33.33 \%$ \\
\hline Total & $2.05 \%$ & $13.84 \%$ & $5.88 \%$ & $87.84 \%$ & $19.62 \%$ & $18.05 \%$ & $14.96 \%$ \\
\hline \multicolumn{8}{|c|}{ Thereof Reported Losses } \\
\hline Losses & $62.15 \%$ & $93.38 \%$ & $77.90 \%$ & $36.01 \%$ & $12.17 \%$ & $85.28 \%$ & $0.62 \%$ \\
\hline Decile $1-5$ & $12.66 \%$ & $30.41 \%$ & $17.25 \%$ & $0.36 \%$ & $2.56 \%$ & $43.03 \%$ & $0.08 \%$ \\
\hline Decile $6-9$ & $9.65 \%$ & $25.58 \%$ & $14.79 \%$ & $0.02 \%$ & $5.17 \%$ & $55.49 \%$ & $0.42 \%$ \\
\hline Decile 10 & $13.87 \%$ & $27.27 \%$ & $8.97 \%$ & $0.05 \%$ & $6.19 \%$ & $59.65 \%$ & $2.42 \%$ \\
\hline Top $1 \%$ & $24.06 \%$ & $29.63 \%$ & $5.59 \%$ & $0.15 \%$ & $4.54 \%$ & $58.27 \%$ & $0.00 \%$ \\
\hline Top $0.1 \%$ & $39.08 \%$ & $22.20 \%$ & $7.60 \%$ & $0.21 \%$ & $2.40 \%$ & $52.08 \%$ & $2.09 \%$ \\
\hline Top $0.01 \%$ & $56.92 \%$ & $13.07 \%$ & $8.38 \%$ & $0.17 \%$ & $2.01 \%$ & $48.38 \%$ & $1.96 \%$ \\
\hline Top $0.001 \%$ & $64.29 \%$ & $11.36 \%$ & $3.10 \%$ & $0.00 \%$ & $1.51 \%$ & $46.69 \%$ & $4.00 \%$ \\
\hline Top $0.0001 \%$ & $75.00 \%$ & $7.69 \%$ & $0.00 \%$ & $0.00 \%$ & $0.00 \%$ & $60.87 \%$ & $22.22 \%$ \\
\hline Total & $11.47 \%$ & $28.09 \%$ & $13.54 \%$ & $0.18 \%$ & $2.44 \%$ & $52.01 \%$ & $0.28 \%$ \\
\hline
\end{tabular}

Source: ITR 2001, own calculations.

1 Income from Agriculture and Forestry - 2 Income from Unincorporated Business $-{ }^{3}$ Income from Self- Employment

$-{ }^{4}$ Income from Wages $-{ }^{5}$ Income from Capital Income $-{ }^{6}$ Income from Renting and Leasing $-{ }^{7}$ Other Income 


\section{References}

Bach, S., Corneo, G. And Steiner, V. (2005): Top Incomes and Top Taxes. DIW Discussion Paper 532

Bach, S., Corneo, G. And Steiner, V. (2007): From Top to Bottom: The Entire Distribution of Market Income in Germany 1992-2001. DIW Discussion Paper 683

Bach, S., Corneo, G. And Steiner, V. (2008): Effective Taxation of Top Incomes in Germany, 1992-2002. CESifo Working Paper 2233

Baldwin, R. H. (1959): How to Assess Investment Proposals. Harvard Business Review, vol. 37, pp. 98-104

Ball, R. (1984): The Natural Taxation of Capital Gains and Losses when Income is Taxed. Journal of Banking and Finance, vol. 8, pp. 471-481

Collins, J. H. And Kemsley, D. (2000): Capital Gains and Dividend Taxes in Firm Valuation: Evidence of Triple Taxation. The Accounting Review, vol. 75, pp. 405-427

Devereux, M. P. And Griffith, R. (1999): The Taxation of Discrete Investment Choices (Revision 2). Working Paper W98/16, The Institute for Fiscal Studies

Federal Ministry of Finance (2001): Datensammlung zur Steuerpolitik. Tech. document. Downloadable at: http://starweb.hessen.de/cache/bund/Datensammlung-zurSteuerpolitik-in-Zahlen\%5B1\%5D.pdf, retrieved 4/24/08

Haisken-DeNew, J. P. And Frick, J. R. (2005): Desktop Companion to the German Socio-Economic Panel (SOEP). Tech. document, DIW Berlin. Downloadable at http://www.diw.de/deutsch/sop/service/dtc/dtc.pdf, retrieved 4/18/2008

Hoffmann, J. And Lorenz, A. (2006): Real Estate Price Indices for Germany: Past, Present and Future. Paper for the OECD-IMF Workshop 7, OECD, Paris

King, M. A. And Fullerton, D. (1984): The Taxation of Income from Capital. Chicago, London

KniRsch, D. (2007): Measuring Tax Distortions with Neutrality-Based Effective Tax Rates. Review of Managerial Science, vol. 1(2), pp. 151-165

Merz, J., Vorgrimmler, D. And Zwick, M. (2006): De Facto Anonymised Microdata File on Income Statistics 1998. Schmollers Jahrbuch, vol. 126, pp. 313-327

MülleR, H. (2004): Das Aufkommen der Steuern vom Einkommen in Deutschland. DUV

Niemann, R., Bachmann, M. And Knirsch, D. (2003): Was leisten die Effektivsteuersätze des European Tax Analyzer? Die Betriebswirtschaft, vol. 63, pp. 123-137

Wagenhals, G. And Buck, J. (2007): Möglichkeiten und Grenzen der Datenfusion für Mikrosimulationsmodelle. In: ZwiCK, M. AND MerZ, J. (Eds.), MITAX - Mikroanalysen und Steuerpolitik, vol. 7 of Statistik und Wissenschaft. Statistisches Bundesamt

Mohlstrasse 36, D-72074 Tuebingen, Germany

E-mail address: martin.jacob@uni-tuebingen.de

Universitätssstrasse 15/G2, A-8010 Graz, Austria

E-mail address: niemann@uni-graz.at

Mohlstrasse 36, D-72074 Tuebingen, Germany

E-mail address: martin.weiss@uni-tuebingen.de 


\section{CESifo Working Paper Series}

for full list see www.cesifo-group.org/wp

(address: Poschingerstr. 5, 81679 Munich, Germany, office@cesifo.de)

2417 Valentina Bosetti, Carlo Carraro, Alessandra Sgobbi and Massimo Tavoni, Modelling Economic Impacts of Alternative International Climate Policy Architectures. A Quantitative and Comparative Assessment of Architectures for Agreement, October 2008

2418 Paul De Grauwe, Animal Spirits and Monetary Policy, October 2008

2419 Guglielmo Maria Caporale, Christophe Rault, Robert Sova and Anamaria Sova, On the Bilateral Trade Effects of Free Trade Agreements between the EU-15 and the CEEC-4 Countries, October 2008

2420 Yin-Wong Cheung and Daniel Friedman, Speculative Attacks: A Laboratory Study in Continuous Time, October 2008

2421 Kamila Fialová and Ondřej Schneider, Labour Market Institutions and their Effect on Labour Market Performance in the New EU Member Countries, October 2008

2422 Alexander Ludwig and Michael Reiter, Sharing Demographic Risk - Who is Afraid of the Baby Bust?, October 2008

2423 Doina Maria Radulescu and Michael Stimmelmayr, The Welfare Loss from Differential Taxation of Sectors in Germany, October 2008

2424 Nikolaus Wolf, Was Germany ever United? Evidence from Intra- and International Trade 1885 - 1933, October 2008

2425 Bruno S. Frey, David A. Savage and Benno Torgler, Noblesse Oblige? Determinants of Survival in a Life and Death Situation, October 2008

2426 Giovanni Facchini, Peri Silva and Gerald Willmann, The Customs Union Issue: Why do we Observe so few of them?, October 2008

2427 Wido Geis, Silke Uebelmesser and Martin Werding, Why go to France or Germany, if you could as well go to the UK or the US? Selective Features of Immigration to four major OECD Countries, October 2008

2428 Geeta Kingdon and Francis Teal, Teacher Unions, Teacher Pay and Student Performance in India: A Pupil Fixed Effects Approach, October 2008

2429 Andreas Haufler and Marco Runkel, Firms' Financial Choices and Thin Capitalization Rules under Corporate Tax Competition, October 2008

2430 Matz Dahlberg, Heléne Lundqvist and Eva Mörk, Intergovernmental Grants and Bureaucratic Power, October 2008 
2431 Alfons J. Weichenrieder and Tina Klautke, Taxes and the Efficiency Costs of Capital Distortions, October 2008

2432 Andreas Knabe and Ronnie Schöb, Minimum Wage Incidence: The Case for Germany, October 2008

2433 Kurt R. Brekke and Odd Rune Straume, Pharmaceutical Patents: Incentives for R\&D or Marketing?, October 2008

2434 Scott Alan Carson, Geography, Insolation, and Institutional Change in $19^{\text {th }}$ Century African-American and White Stature in Southern States, October 2008

2435 Emilia Del Bono and Daniela Vuri, Job Mobility and the Gender Wage Gap in Italy, October 2008

2436 Marco Angrisani, Antonio Guarino, Steffen Huck and Nathan Larson, No-Trade in the Laboratory, October 2008

2437 Josse Delfgaauw and Robert Dur, Managerial Talent, Motivation, and Self-Selection into Public Management, October 2008

2438 Christian Bauer and Wolfgang Buchholz, How Changing Prudence and Risk Aversion Affect Optimal Saving, October 2008

2439 Erich Battistin, Clara Graziano and Bruno Parigi, Connections and Performance in Bankers' Turnover: Better Wed over the Mixen than over the Moor, October 2008

2440 Erkki Koskela and Panu Poutvaara, Flexible Outsourcing and the Impacts of Labour Taxation in European Welfare States, October 2008

2441 Marcelo Resende, Concentration and Market Size: Lower Bound Estimates for the Brazilian Industry, October 2008

2442 Giandomenico Piluso and Roberto Ricciuti, Fiscal Policy and the Banking System in Italy. Have Taxes, Public Spending and Banks been Procyclical in the Long-Run? October 2008

2443 Bruno S. Frey and Katja Rost, Do Rankings Reflect Research Quality?, October 2008

2444 Guglielmo Maria Caporale, Antoaneta Serguieva and Hao Wu, Financial Contagion: Evolutionary Optimisation of a Multinational Agent-Based Model, October 2008

2445 Valentina Bosetti, Carlo Carraro and Massimo Tavoni, Delayed Participation of Developing Countries to Climate Agreements: Should Action in the EU and US be Postponed?, October 2008

2446 Alexander Kovalenkov and Xavier Vives, Competitive Rational Expectations Equilibria without Apology, November 2008 
2447 Thiess Buettner and Fédéric Holm-Hadulla, Cities in Fiscal Equalization, November 2008

2448 Harry H. Kelejian and Ingmar R. Prucha, Specification and Estimation of Spatial Autoregressive Models with Autoregressive and Heteroskedastic Disturbances, November 2008

2449 Jan Bouckaert, Hans Degryse and Thomas Provoost, Enhancing Market Power by Reducing Switching Costs, November 2008

2450 Frank Heinemann, Escaping from a Combination of Liquidity Trap and Credit Crunch, November 2008

2451 Dan Anderberg, Optimal Policy and the Risk Properties of Human Capital Reconsidered, November 2008

2452 Christian Keuschnigg and Evelyn Ribi, Outsourcing, Unemployment and Welfare Policy, November 2008

2453 Bernd Theilen, Market Competition and Lower Tier Incentives, November 2008

2454 Ondřej Schneider, Voting in the European Union - Central Europe's Lost Voice, November 2008

2455 Oliver Lorz and Gerald Willmann, Enlargement versus Deepening: The Trade-off Facing Economic Unions, November 2008

2456 Alfons J. Weichenrieder and Helen Windischbauer, Thin-Capitalization Rules and Company Responses, Experience from German Legislation, November 2008

2457 Andreas Knabe and Steffen Rätzel, Scarring or Scaring? The Psychological Impact of Past Unemployment and Future Unemployment Risk, November 2008

2458 John Whalley and Sean Walsh, Bringing the Copenhagen Global Climate Change Negotiations to Conclusion, November 2008

2459 Daniel Mejía, The War on Illegal Drugs in Producer and Consumer Countries: A Simple Analytical Framework, November 2008

2460 Carola Frydman, Learning from the Past: Trends in Executive Compensation over the Twentieth Century, November 2008

2461 Wolfgang Ochel, The Political Economy of Two-tier Reforms of Employment Protection in Europe, November 2008

2462 Peter Egger and Doina Maria Radulescu, The Influence of Labor Taxes on the Migration of Skilled Workers, November 2008

2463 Oliver Falck, Stephan Heblich and Stefan Kipar, The Extension of Clusters: Differencein-Differences Evidence from the Bavarian State-Wide Cluster Policy, November 2008 
2464 Lei Yang and Keith E. Maskus, Intellectual Property Rights, Technology Transfer and Exports in Developing Countries, November 2008

2465 Claudia M. Buch, The Great Risk Shift? Income Volatility in an International Perspective, November 2008

2466 Walter H. Fisher and Ben J. Heijdra, Growth and the Ageing Joneses, November 2008

2467 Louis Eeckhoudt, Harris Schlesinger and Ilia Tsetlin, Apportioning of Risks via Stochastic Dominance, November 2008

2468 Elin Halvorsen and Thor O. Thoresen, Parents' Desire to Make Equal Inter Vivos Transfers, November 2008

2469 Anna Montén and Marcel Thum, Ageing Municipalities, Gerontocracy and Fiscal Competition, November 2008

2470 Volker Meier and Matthias Wrede, Reducing the Excess Burden of Subsidizing the Stork: Joint Taxation, Individual Taxation, and Family Splitting, November 2008

2471 Gunther Schnabl and Christina Ziegler, Exchange Rate Regime and Wage Determination in Central and Eastern Europe, November 2008

2472 Kjell Erik Lommerud and Odd Rune Straume, Employment Protection versus Flexicurity: On Technology Adoption in Unionised Firms, November 2008

2473 Lukas Menkhoff, High-Frequency Analysis of Foreign Exchange Interventions: What do we learn?, November 2008

2474 Steven Poelhekke and Frederick van der Ploeg, Growth, Foreign Direct Investment and Urban Concentrations: Unbundling Spatial Lags, November 2008

2475 Helge Berger and Volker Nitsch, Gotcha! A Profile of Smuggling in International Trade, November 2008

2476 Robert Dur and Joeri Sol, Social Interaction, Co-Worker Altruism, and Incentives, November 2008

2477 Gaëtan Nicodème, Corporate Income Tax and Economic Distortions, November 2008

2478 Martin Jacob, Rainer Niemann and Martin Weiss, The Rich Demystified - A Reply to Bach, Corneo, and Steiner (2008), November 2008 